\title{
Effect of Number Head Together and Talking Stick Types of Cooperative Learning Model on Redoks Towards Student's Motivation and Learning Outcomes
}

\author{
Rufinah. S \\ Universitas Tadulako \\ Palu, Indonesia \\ rufisubrantas@gmail.com \\ Siti Nuryanti \\ Universitas Tadulako \\ Palu, Indonesia \\ sitinoer_untad@yahoo.com
}

\author{
Kasmudin Mustapa \\ Universitas Tadulako \\ Palu, Indonesia \\ kasmudinfkipuntad@gmail.com
}

\begin{abstract}
Learning success in the sense of achieving the standard of competence was very dependent on the ability of teachers learning the process. Therefore, the researcher applies cooperative learning model that was suitable for improved students' motivation and enthusiasm that cooperative learning model Number Head Together and Talking Stick. This study aimed to determine the effect of cooperative learning model Numbered Head Together and Talking stick to the motivation and learning outcomes of students' class $X$ on the material of redox reactions in SMAN 1 Poso Pesisir Utara. This research was a preexperimental with the static pretest-posttest group design. The samples of this study were students $\mathrm{Xa}$ as a class experiment 1 and the total student was 31 students than student $X c$ as a class experiment 2 has 32 students. The results of data analysis, the average value $\left(\bar{X}_{1}\right)$ class experiment 1 is 68.21 and $\left(\bar{X}_{2}\right)$ the class experiment 2 is 62.00. Results of testing hypotheses by statistical $t$-test two parties obtained $t$ - $t_{\text {able }} \leq t_{\text {count }} \geq+t_{\text {-table }}\left(t_{\text {-count }}=\right.$ 48,22 for class experiment $1 ; t_{\text {-count }}=55,59$ for class experiment 2 and $t_{\text {-table }}=1.67$ ) with a significance level $\alpha=0.05$ and degrees of freedom 61, then $\mathrm{H}_{0}$ rejected and $\mathrm{H}_{\mathrm{a}}$ be accepted. The results of data analysis of student learning motivation questionnaire showed that the experimental class 1 was the attitude of "agree" with the positive category was $83.69 \%$ and the experimental class 2 are in the attitude of "agree" with the positive category was $83.77 \%$. It can be concluded that there was the influence of cooperative learning model Number Head Together and Talking stick on redox towards students to the motivation and learning outcomes.
\end{abstract}

Keywords-Numbered Head Together; Talking Stick; Motivation; Learning Outcomes; Redox.

\section{INTRODUCTION}

Education as one of the main pillars which play an important role in the development process of Indonesia to ensure the survival of a Nation because education can improve and develop the quality of human resources. The life of a nation in the globalization era need high competence because higher the competence of a nation made a higher level of ability to resolve various issues happened [1].

Education was an important role in the progress of a nation. Therefore, the quality education needed to advance a nation. The quality of education can be improved by improving the system of learning education. Learning system can be improved by improving the quality of learning. The quality of learning can be affected by several factors such as students, teachers, curriculum, teaching methods and facilities [2].

The curriculum used in the SMAN 1 Poso Pesisir Utara was the Education Unit Level Curriculum (SBC). Saw these conditions the researchers in this case would like to be able to present the models of learning interesting, effective and efficient in the learning process so that the learning atmosphere in the classroom become more active and students are increasingly motivated to follow the learning process in the classroom with the hope of learning outcomes of students was increased. Chemistry was essentially a way to find out and understand about nature systematically, so the chemistry was not taught just by simply given an understood of notions, facts, concepts, principles, but also built knowledge of individually and teachers act as a mediator [3].

The concept of chemistry is abstract and interrelated, included the redox material. Studying the concept of redox necessary conceptual and algorithmic well so that it can easily 
be taught to students. The material of redox reactions that were abstract suitable when taught by students with a learning model that involves students actively in understood the concepts in the material oxidation-reduction reaction. Model appropriate learning includes learning the cooperative model.

Cooperative learning model was a model that prioritizes the groups, every student in the group has the ability vary levels and if possible, members come from various of racial, cultural, ethnic and religious backgrounds. Cooperative learning was arranged in an effort to increase student participation, facilitated students to experience leadership attitudes and made decisions within the group as well as provide opportunities for students to interacted and the student learns together with different backgrounds [4].

Learning success in the sense of achieving the standard of competence, highly dependent on the ability of teachers learning the process. Some cooperative learning model that applied to the material suitable for a redox reaction at SMAN 1 Poso Pesisir Utara in order to increase the motivation and enthusiasm of student learning was cooperative learning model Numbered Head Together (NHT) and Talking Stick (TS).

NHT cooperative learning was one type of cooperative learning that emphasizes in special structures designed to affect the pattern of interaction of students and has a goal to increase academic mastery. Cooperative learning model type NHT was learning strategy that has collaboration among the students in the group to achieve the learning objectives [5]. TS was one method that can be used in innovative learning model studentcentered. Model TS was a method of learning with the aid of a cane, who took a stick obliged to answer questions from teachers after the students learn substantially subject [6].

Cooperative learning model applied in chemistry learning course would produce learning outcomes and good cooperation skills in learners. The use of cooperative learning model which was right in chemistry will be able to improved learning outcomes, cooperation, and skills of students [7]. It was the background of the author to conduct research in SMA 1 Poso Pesisir Utara. Researcher feel it was important to look at the extent of the influence of the learning model that was given to motivation and learning outcomes produced by the students and the researcher hope that the implementation of cooperative learning model $N H T$ and $T S$ can be used as an alternative to problem solving that found during the learning process, Based on the background, the researcher were encouraged to conduct research with the title " Effect of number head together and talking stick types of cooperative learning model on redoks towards student's motivation and learning outcomes ".

\section{METHOD}

The research was conducted in SMA Negeri 1 Poso Pesisir Utara. The type of this research was pre-experimental research with the design of the static pretest-posttest group design. The population of this research was students of class $\mathrm{X}$ with the total sampling technique was purposive sampling method. The sample contained was graders Xa as a class experiment 1 and $\mathrm{Xc}$ graders students as a class experiment 2.

\section{A. Research Instruments}

This study used an instrument that tests of learning outcomes and student motivation in the form of a questionnaire. The achievement test used to determine whether or not there was the effect of the application of learning models were applied to the learning outcomes of students in the second-grade chemicals were selected as sample. While the motivation questionnaire was used to determine the level of student motivation in participated in the learning process. Achievement test was organized into as many as 17 items of multiple choice with 5 possible answers, motivation questionnaire composed of 25 items consisted of five indicators, namely indicators of attention, interest, liveliness, satisfaction, and confidence. Test student learning outcomes arranged with a view for obtaining the data of student learning outcomes after learning that to know whether or not there was influence cooperative learning model NHT and TS on the results of class X student of SMAN 1 Poso Pesisir Utara on the subject of redox reactions. While the questionnaire was used to determine the level of student motivation in participated in the learning process. This research was starred in three phases: preparation, the implementation phase, and the final stage.

\section{B. Data Analysis Techniques}

The data were analyzed by the inferential statistical analysis method. An inferential statistical analysis was used to test hypotheses and made generalizations [8].

\section{RESULTS AND DISCUSSION}

\section{A. Results}

1) Student Motivation

Based on the research conducted, the data obtained grade student motivation and classroom experiment 1 and experiment 2, as follows:

TABle I. DATA Student Motivation Class EXPERIMENT 1 AND Class EXPERIMENT 2

\begin{tabular}{|l|l|l|l|l|}
\hline \multicolumn{1}{|c|}{ Information } & \multicolumn{2}{|c|}{ Experiment 1 } & \multicolumn{2}{c|}{ Experiment 2 } \\
\hline & Before & After & Before & After \\
\hline Total Student & 31 & 31 & 32 & 32 \\
\hline Lowest Score & 73 & 88 & 78 & 91 \\
\hline Maximum Score & 125 & 125 & 125 & 125 \\
\hline$\%$ Average & 75,77 & 83,69 & 78,39 & 83,77 \\
\hline Attitude & Agree & Agree & Agree & Agree \\
\hline Category & Positive & Positive & Positive & Positive \\
\hline
\end{tabular}

\section{2) Student Results}

Based on the research, student learning outcomes data obtained class experimental 1 and class experiment 2 , as follows: 
TABle II. Data Student Results Class EXPERIMENT 1 AND Class EXPERIMENT 2

\begin{tabular}{|l|c|c|c|c|}
\hline \multirow{2}{*}{ Information } & \multicolumn{2}{|c|}{ Experiment 1 } & \multicolumn{2}{c|}{ Experiment 2 } \\
\cline { 2 - 5 } & Pretest & Posttest & Pretest & Posttest \\
\hline Samples & 31 & 31 & 32 & 32 \\
\hline Lowest Score & 6 & 35 & 6 & 35 \\
\hline The Highest Score & 29 & 94 & 23 & 94 \\
\hline Average Score & 16,13 & 68,21 & 13,63 & 62,00 \\
\hline Standard deviation & 6,75 & 14,77 & 5,77 & 16,06 \\
\hline
\end{tabular}

\section{3) $\mathrm{N}$-Gain Test}

Based on the results obtained after the initial test and final test, descriptive data obtained for the n-gain test. Testing $\langle\mathrm{g}\rangle$ conducted to analyze the data in ways that describe or depict the data that has been collected based on the achievement every variable in relation to the value of pretest and posttest of students in the class experiment 1 and class experiment 2 .

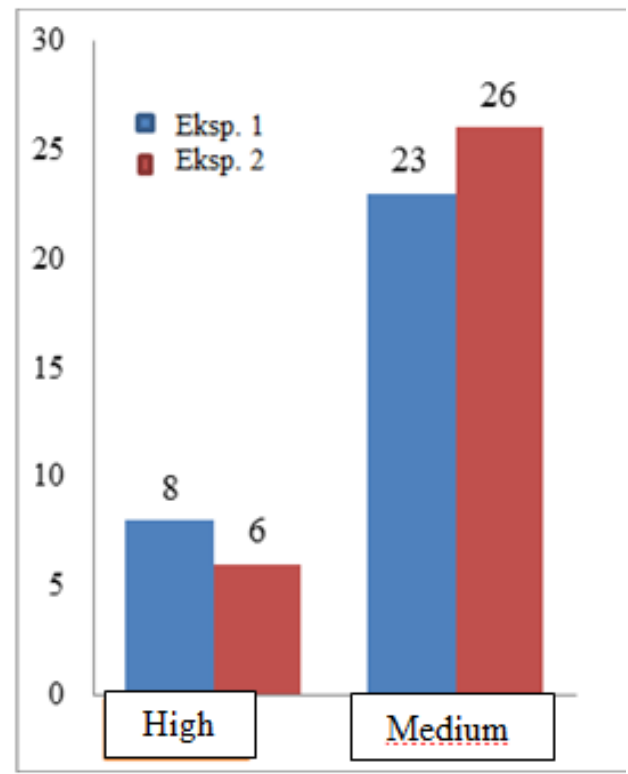

Fig. 1 N-Gain Testing Students in Class Experiment 1 and Class Experiment 2

\section{B. Discussion}

According to the Table I, we can say that the results of descriptive analysis of criteria or categories of level of student motivation toward learning model NHT application of the concept of redox currently on attitudes agrees with the positive category are $83.69 \%$. While the level of student motivation toward learning model application $T S$ is also in attitude agreed with the positive category is $83.77 \%$. Based on the results the percentage criteria or categories of class experiment 1 and class experiment 2 , it can be said that the application of the learning model NHT and TS influence on students' motivation. Reference provided a theoretical framework for understanding the effect of different modes of instruction and further distinguished between three ways in which the motivations of different individuals can be interrelated within cooperative, competitive, and individualistic [9].
Motivation questionnaire used in this study consists of five indicators of motivation described in any statement of the questionnaire with the average value of the rates for the class experiment 1 and class experiment 2, by consecutive manner: attention $83.61 \%$ and $85.12 \%$, interest $82.32 \%$ and $83.00 \%$, $86.32 \%$ and 85.75 liveliness $\%$ satisfaction $83.74 \%$ and $83.25 \%, 82.45 \%$ and 81.75 belief $\%$. Based on the percentage of these indicators were all in the positive category, it will be created at each individual student matters related to attention, interest, liveliness, satisfaction, and confidence in learning.

Student learning outcomes were measured using the instrument written test that has been validated and given to students before (pretest) and after (post-test) are given learning. The instrument was then analyzed using descriptive statistical analysis and inferential statistical analysis [10].

According to the table 2 for student learning outcomes can be seen that for the class experiment 1 or class experiment 2 increased from the pretest to posttest results of this signifies that the influence of the learning model was applied both of class.

Based on the research results obtained from both of class for descriptive statistical analysis, the $\mathrm{N}$-gain test was used to determine the correlation value of pretest and posttest class experiment 1 and class experiment 2 or see improved student learning outcomes based on data pretest and posttest [11], the result of the class experiment 1 and class experiment 2 consecutive experiments: the low category 0 (no of students in the low category), the category of being 23 and 27, the high category 8 and 5 people. This shows the class experiment $1 \mathrm{~N}$ Gain increased higher than the class experiment 2.

The results of calculations on the data normality posttest class experiment 1 data obtained $\chi_{\text {count }}^{2}=6,27$ and $\chi_{\text {table }}^{2}=7,81$. The complete result the criteria of normal distribution of data, namely $\chi_{\text {count }}^{2} \leq \chi_{\text {table }}^{2}$ was $6,27<7,81$. The results of normality calculations on the data obtained posttest class experiment 2 $\chi_{\text {count }}^{2}=4,23$ and $\chi_{\text {table }}^{2}=7,81$. The complete results criteria of the normal distribution of data, namely $\chi_{\text {count }}^{2} \leq \chi_{\text {table }}^{2}$ were 4,23 $<7,81$. Homogeneity testing was done by using $\mathrm{F}$ (equality of two variants). The variance $=16.06$ while the smallest variance $=14.77$. Obtained value of $F_{\text {count }}=1.09$ and $F_{\text {table }}=2.38$. Then the data was complete the criteria of data homogeneous $\mathrm{F}_{\text {count }}<$

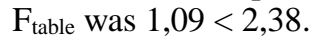

Based on this hypothesis that there was an influence on the implementation of cooperative learning model $N H T$ and there was the influence of TS learning model application the student learning outcome of class $\mathrm{X}$ in a redox reaction material in SMAN 1 Poso Pesisir Utara. Then the hypothesis was conducted by t-test two sides. Price $t_{(0.95)}$ with dark $=61$ from the distribution list of students is 1.67 , the testing criteria were if $-\mathrm{t}_{\text {-table }} \leq \mathrm{t}_{\text {-hit }} \leq+\mathrm{t}_{\text {tabel }}(1-\alpha),\left(\mathrm{n}_{1}+\mathrm{n}_{2}-2\right) \mathrm{H}_{0}$ is accepted and $\mathrm{H}_{\mathrm{a}}$ is rejected. Based on the results obtained by $-1.67<48.22>$ +1.67 for the class experiment 1 which shows that clearly was in the region so that $\mathrm{H}_{0}$ is rejected and $\mathrm{Ha}$ is received, it means that was a learning model NHT influence on student learning outcomes. As for the class experiment 2 based on the results obtained $-1.67<55.59\rangle+1.67$ which indicates that a clear rejection of $\mathrm{H}_{0}$ was in the region so that $\mathrm{H}_{0}$ rejected and $\mathrm{Ha}$ is 
received, it means that was a learning model $T S$ influence on student learning outcomes.

This study was conducted to investigate the effect of the learning model $N H T$ and TS on the motivation and student learning outcomes in a redox reaction material in class X SMA Negeri 1 Poso Pesisir Utara. The object of research used in this research were two groups of class, $\mathrm{Xa}$ as a class experiment 1 and $\mathrm{Xc}$ as a class experiment 2. Implementation of research in the experimental group 1 and experimental group 2 uses the same amount of instructional time, which is 6 hours of lessons. In addition to learning the same amount of time, the subject matter presented in the experimental group 1 and group 2 are also the same experimental the concept of redox reactions with the same sequence of delivery of material anyway. Different treatment only in the learning model is used, where the first experimental group using NHT learning model, while the experimental group using model $2 T S$.

Cooperative learning model type NHT was a variation of the characteristic of group discussion is to appoint a teacher of students who represent the group without telling in advance who will represent the group [12]. NHT emphasized the students' responsibility. This learning model fostered the students to learn the material given as well as to examine their comprehension. NHT provided times for students to think and find appropriate solutions [13]. One way to improve the learning process and learning results are to use the NHT learning strategy. The use of this model can make the learners to be involved in the thinking activity so that they can be directly involved in the learning process. The involvement of students in the learning process can improve their understanding and knowledge [14].

The implementation of cooperative learning model NHT can increase student competence in reading comprehension in the learning process, students seemed happy and excited so that they become active and creative. This occurs because the cooperative learning model $N H T$ number of members comprised of 3-4 people. Grouping students can encourage their involvement in the learning process [15]. Implementation of the learning model NHT makes the atmosphere more conducive to student learning and learning activities in a more student-centered [16].

The learning model TS has also the characteristics and advantages of the creation of social attitudes are high among the members of the group because if students took a stick to answer the next class cannot answer correctly then fellow member of group can help each other to answer that question, test readiness of learners in the learning process, and increasing willingness to use other people's ideas are perceived better. By implemented for the student these methods, it was better for them to work together in groups for solving the problems and help one another to understand the course better, students have to be more discipline and be more self-assertive in doing the tasks given by the lecturer [17]. During $T S$ technique was implemented in the classroom, all students did face to face interaction because they worked together and face to face in the group. Besides, it also happened simultaneous interaction because, in the group, they cooperated and interacted with one student to other students. Next, it happened individual accountability because every student in the group must be responsible for their task or role. The last, it also occurred equal participation because all students were given equal opportunity to speak [18].

Students increase motivation was one integral activity that must exist in the learning activities. Students in the social and cultural environment that tends to be passive and silent then the mindset that found within them that was difficult to interact and actively engaged with other students [19]. In addition to providing and transferring science teachers also served to increase the child's motivation to learn. We cannot deny that student motivation one another very different, that's important for teachers always give motivation to students so that students always have the spirit of learning and being able to be students who excel and can develop themselves optimally. The learning process will be successful when students are motivated to learn. Chemistry applied learning approach also reflects the emphasis on technology in the cultural patterns [20]. Optimal learning results can be obtained by improving student motivation through the creativity of teachers in managing learning. One way that can be done to improve students' motivation was to apply an interesting learning model.

Based on current trends in education which point toward the increased use of distance learning and research on the benefits of cooperative learning at all levels, this study investigated the effectiveness of specific cooperative learning strategies in discussion boards, a commonly used distance learning tool which fosters student engagement online [21]. Cooperative learning consists of five basic elements: positive interdependence, promotive interaction, individual accountability, the teaching of interpersonal and social skills, and quality of group processing [22].

Results of testing the hypothesis that suggests that there was the influence of the learning model NHT and TS on student learning outcomes and based on the results of pre-test and the results of the posttest students, it can be said that the learning model NHT and TS effective in giving a positive influence on the results of class X student of SMAN 1 Poso Pesisir Utara.

The effectiveness of learning was not only seen from the results of student learning but also emphasized the effectiveness of learning at the level of teacher's ability to manage the learning and mastery level of learning strategies and teachers against suitability rate of time spent during the process. In addition, the effectiveness of learning can also be measured by looking at the interest or motivation of learners towards learning activities so that students are actively involved in the learning process [23]. It was also in accordance with the opinion of [24], which states that the factors of affect student learning outcomes from within was the students' interest and motivation. Based on these opinions so that in this study except visible influence learning model NHT and TS on learning outcomes, the views also influence on the students' motivation in participating in the learning process. Cooperative learning was included in science lessons that can provide a good understanding to achieve competence in learning [25].

\section{CONCLUSION}

The conclusion of this study was: 
1. There was a learning model NHT influence on student learning outcomes in redox material in class X SMA Negeri 1 Poso Pesisir Utara. The average score posttest of the class experiment 1 was 68.21 and based on descriptive statistics on student motivation after being given the treatment showed that the class experiment 1 were in attitude agree with the positive category was $83.69 \%$ and the N-Gain test show average results 0.63 in the medium category which describes that improved student learning outcomes from the pretest to posttest results of the class experiment 1 was enough high.

2. There was a learning model TS influence on student learning outcomes in redox material in class X SMA Negeri 1 Poso Pesisir Utara. The average score posttest of the class experiment 2 was 62.00 and based on descriptive statistics on student motivation after being given the treatment showed that the class experiment 2 were in attitude agree with the positive category was $83.77 \%$ and the N-Gain test show average results 0.56 in the medium category which describes that improved student learning outcomes from the pretest to posttest results of the class experiment 2 was enough high.

\section{ACKNOWLEDGEMENT}

The researcher extends her great appreciation to all teacher and students chemistry class Xa and Xc SMA Negeri 1 Poso Pesisir Utara. The special appreciation to who has supported helped, and suggestion in complete the research.

\section{REFERENCES}

[1] J. S. T. Kasman, Mangara Sihaloho, "The effect of applied the method Talking Stick on learning outcomes in grade colloidal material on XI IPA SMA Negeri 2 Gorontalo," J. KIM Fak. Mat. and IPA, vol. 2, no. 2, pp. $1-9,2014$

[2] Slameto. (2003). Learn and Factors that Influence. Jakarta: Rineka Copyright.

[3] Sanjaya, Wina. (2007). Learning Strategies Oriented Educational Process Standards. Jakarta: Kencana.

[4] E. Jayanti, Ardana, and Putra, "The implementation of cooperative learning model NHT on learning outcomes V IPA grade students of primary school cluster LT. WISNU Denpasar North," J. Mimb. PGSD Univ. Educ. Ganesha, vol. 2, no. 1, pp. 13-21, 2014.

[5] Trianto. (2007). Innovative Teaching Models Constructivist-oriented: The Concept of a Theoretical Foundation and the Practical Implementation. Jakarta: Achievement Botanical Library.

[6] Suprijono, A. (2011). Cooperative Learning Theory and Application PAIKEM. Yogyakarta: Library Study.

[7] L. Khusna, J. Suprihatiningrum, K. Osman, and Supiana, "The Influence of Cooperative Learning Model of Type Numbered Heads Together (NHT) and Type Think Pair Share (TPS) against Results Study of Chemistry and Cooperation Skills," First J. Int. Semin. Chem. Educ., vol. 2, no. 2, pp. 48-53, 2015.

[8] Sudjana, N dan Ibrahim. (2012). Research and Evaluation of Education. Bandung: New Ray Algensindo.
[9] A. Olarewaju, A. Awofala, A. O. Fatade, and S. A. Ola-oluwa, "Achievement in Cooperative versus Individualistic Goal-Structured Junior Secondary School Mathematics Classrooms in Nigeria," Int. J. Math. Trends Technol., vol. 3, no. 1, pp. 7-12, 2012.

[10] Sugiyono. (2010). Statistic for Research. Bandung: Alfabeta.

[11] Wulandari, A.D., Kurnia. and Sunarya, Y. "Guided inquiry-based learning lab to enhance the critical thinking skills of high school students on the reaction rate", Jurnal Riset dan Praktik Pendidikan Kimia. vol 1, no. 1, pp. 18-26, 2013.

[12] Munawaroh, "The Comparative Study Between The Cooperative Learning Model Of Numbered Heads Together ( NHT ) And Student Team Achievement Division ( Stad ) To The Learning Achievement In Social Subject," IOSR J. Res. Method Educ., vol. 5, no. 1, pp. 24-33, 2015 .

[13] A. D. C. Marleny Leasa, "The effect of numbered heads together (NHT) cooperative learning model on the cognitive achievement of students with different academic ability,” IOP Sci. J. Phys., vol. 10, no. 1, pp. 95103, 2016.

[14] S. Y. Nursyamsi and A. D. Corebima, "THE EFFECT OF NUMBERED HEADS TOGETHER (NHT) LEARNING STRATEGY ON THE RETENTION OF SENIOR HIGH SCHOOL STUDENTS IN MUARA BADAK.” Eur. J. Educ. Stud., vol. 2, no. 5, pp. 47-58, 2016.

[15] M. Maman and A. A. Rajab, "The Implementation of Cooperative Learning Model ' Number Heads Together ( NHT )' in Improving the Students ' Ability in Reading Comprehension," Int. J. Eval. Res. Educ., vol. 5, no. 2, pp. 174-180, 2016.

[16] Y. Miaz, "The Implementation Of Numbered Heads Together To Improve The Student's Achievement Of Social Sciences In Primary School,” Res. J. Soc. Sci., vol. 8, no. 10, pp. 40-45, 2015.

[17] L. W. Wardana, "Paper Airplane and Talking Stick Learning Methods To Increase Students Understanding About Management Information System Courses," IOSR J. Bus. Manag., vol. 18, no. 9, pp. 164-169, 2016.

[18] Rizky Oktaviana, "IMPLEMENTATION OF COOPERATIVE LEARNING WITH TALKING CHIPS TECHNIQUE ON SOLIDS MATERIAL," Proceeding Int. Conf. Res. Implement. Educ. Math. Sci., vol. 9, no. 7, pp. 18-20, 2014.

[19] K. Magil, "Hope, Rage, and Inequality: A Critical Humanist Inclusive Education," Int. J. Progress. Educ., vol. 11, no. 1, pp. 6-9, 2015.

[20] A. Kahveci, P. J. Gilmer, and S. A. Southerland, "Understanding Chemistry Professors ' Use of Educational Technologies : An activity theoretical approach," Int. J. Sci. Educ., vol. 30, no. 3, pp. 325-351, 2008.

[21] L. Kupczynski, M. A. Mundy, A. Texas, V. Meling, A. Texas, and M. U.- Kingsville, "COOPERATIVE LEARNING IN DISTANCE LEARNING : A MIXED METHODS STUDY," Int. J. Instr., vol. 5, no. 2, pp. 82-92, 2012.

[22] V. D. Tran, A. Giang, and A. Giang, "The Effects of Cooperative Learning on the Academic Achievement and Knowledge Retention," Int. J. High. Educ., vol. 3, no. 2, pp. 131-140, 2014.

[23] E. Zakaria and Z. Iksan, "Promoting Cooperative Learning in Science and Mathematics Education: A Malaysian Perspective," Eurasia J. Math. Sci. Technol. Educ., vol. 3, no. 1, pp. 35-39, 2007.

[24] K. . Aritonang, "Interest and motivation in improving student learning outcomes," J. educ. Penabur, vol. 10, no. 7, pp. 11-21, 2008.

[25] R. K. Coll and C. Eames, "Learning science and technology through cooperative education," Asia-Pasific J. Coop. Educ., vol. 8, no. 2, pp. 131-147, 2007. 